\title{
Community Safety, Social Cohesion and Embedded Autonomy: a Case from South-West Dublin
}

\author{
Matt Bowden \\ Technological University Dublin, Matt.Bowden@TUDublin.ie
}

Follow this and additional works at: https://arrow.tudublin.ie/aaschsslarts

Part of the Environmental Studies Commons, and the Sociology Commons

\section{Recommended Citation s41300-017-0018-3 \\ This Article is brought to you for free and open access by the Social Sciences at ARROW@TU Dublin. It has been accepted for inclusion in Articles by an authorized administrator of ARROW@TU Dublin. For more information, please contact arrow.admin@tudublin.ie, aisling.coyne@tudublin.ie,gerard.connolly@tudublin.ie.}

Bowden, M. (2017). Community safety, social cohesion and embedded autonomy: a case from south-west Dublin. Crime Prevention and Community Safety, vol. 19, no. 2, pg. 87-102. doi:10.1057/

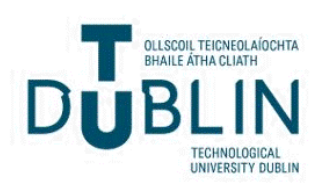


Community Safety, Social Cohesion and Embedded Autonomy: A Case from South-West Dublin.

Matt Bowden, Senior Lecturer, School of Languages, Law and Social Sciences, Dublin Institute of Technology, Ireland.

Contact:

Dr Matt Bowden

School of Languages, Law and Social Sciences

Dublin Institute of Technology

Rathdown House

Grangegorman

Dublin 7

Ireland

Matt.bowden@dit.ie; Tel: 35314024230

Published as Bowden, M. (2017) Crime Prevention and Community Safety, 19(2) doi:10.1057/s41300-017-0018-3 


\begin{abstract}
The article provides a case of community safety based upon an evaluative study of an community safety intervention in the south-west Dublin suburb of Tallaght.

Characteristic of the Irish context for crime prevention and community safety has been the ad hoc nature of policy formation and the underdeveloped structures for urban security. The case is based primarily upon qualitative data from interviews and focus groups with key stakeholders, together with some additional observations from a household survey. The key themes centre on the way safety manifests from issues related to social integration in the pilot communities; the impact, capacity and potential of the local authority as an agent for urban security; the creative tension between evidence based approaches and practical problem solving; and the role of community safety workers' local knowledge and autonomous action within the local authority structures.
\end{abstract}

Keywords

Urban security, community safety, crime prevention, local security governance, Ireland. 


\section{Introduction}

The article presents the case material from an evaluative study of a community safety initiative in south-west Dublin, outlining the role of the funder, the deployment of the cross agency team, and examples of the community level practices that were deployed.

Critical lessons here relate to how safety manifests in social housing estates; and the role of the local authority, given its statutory responsibilities in Ireland in respect of housing and estate management, together with its statutory powers regarding antisocial behaviour. The Initiative in Tallaght West was made possible by the Childhood Development Initiative (CDI) a consortium of agencies and individuals working to improve services and outcomes for children. The case reveals the centrality of the local authority as a multi functional unit of local governance and its role in combining social prevention interventions together with situational measures in social housing contexts. Of interest here also is the minimal and understated role of the formal police organisation, An Garda Síochána, and hence revealing the 'nodal' nature of the governance of security (Shearing and Wood, 2003; Wood and Shearing, 2007). Community safety has many manifestations and labels depending upon the national context in which it is used. Edwards et al (2013) note that the term 'urban security' in continental Europe captures a wide range of informal interventions in crime prevention and crime control. In so far as ordering and security are functions of the governance of social space, and by virtue of its implied work in social integration and social cohesion as revealed in this case, the local state is a key actor in governing security beyond the criminal justice system. 
Despite the literature emphasising the emergence of a 'punitive turn' and 'cultures of control' (Garland, 2001), the practice of community safety workers' received attention for their capacity to act within both liberal and social democratic frameworks (Hughes and Gilling 2004; Hughes 2007). Moreover, the role of the community safety worker reflected a dilemma between mobilising agents for a 'new moral cleansing' as against enabling the formation of 'radical cadres of transformative power' (Hughes et al, 2002: 167). Applying this in the Australian context, Cherney and Sutton (2004) noted that while the role of the Community Safety Officer was framed within the technical fix of 'what works', in practice their work focused much more on proactive problem-solving with a multiplicity of governing actors. They also noted the need for flexible and semi-autonomous work by de-emphasising law and order responses; and acting as catalysts to change mindsets towards practical resolutions.

This article introduces case material from the Republic of Ireland - a relative latecomer to the community safety ball - to discuss some of these issues and to highlight some of the complexities and nuances revealed in the research. A first step is to set out some characteristics of the Irish context, followed by the empirical material from the Tallaght West Community Safety Initiative study.

\section{Key Aspects of the Irish Context}

Documenting the development of crime prevention and community safety in the Republic of Ireland, Bowden and Topping (2016) outline that the 'preventive turn' 
(Hughes, 2007) has had a bottom-up, and indeed a middle-out quality based upon a combination of pragmatic reforms in care and welfare systems. Indeed developments in crime prevention and locally based informal crime control stem from a variety of sources. For example, the closure of Industrial Schools in the 1970s gave rise to a greater diffusion of social prevention initiatives (Sargent 2014; Bowden and Topping 2016); youth crime and disorder prevention in urban peripheral neighbourhoods emerged in direct response to problems associated with youth disorder in urban periphery in the 1990s (Bowden 2006; Bowden 2014; Bowden and Higgins, 2000). The National Drug Strategy, initiated in 1996 as a response to two definable heroin epidemics in Dublin (peaking first in 1983 and a later peak in 1995), has also been a key player in prevention and safety measures through a network of Local Drugs Task Forces (Bowden and Topping, 2016). On balance while there is increasing activity in both crime prevention and community safety, they have been germinated in a variety of domains: in urban regeneration; estate management; and early childhood interventions (Gilling et al, 2013).

In the Irish context, questions of social order in social housing estates remain a critical issue for planners and managers. Research by Fahey (1999) and more recently by O’Gorman (2014) also highlight that nuisance and disorder are key factors shaping quality of life and determining the success or failure of social housing developments. Previous state interventions in the Irish context such as incentives to enable tenants to purchase houses and relinquish their tenancies have contributed much to disorder by removing most economically stable tenants from estates (O'Connell and Fahey 1999; Hourigan 2011). 
During the 1990s and 2000s a number of local development initiatives were established under a combination of support from the Irish government and the European Commission that were directly focused upon countering social exclusion. One of these developments the RAPID programme (Revitalising Areas Through Planning, Investment and Development) channelled Irish exchequer funding to the most disadvantaged areas in the State between 2002 and 2010. A key dimension of RAPID, which was implemented by local authorities, was to propose strategies to deal with anti-social behaviour and to promote community safety (Bowden and Topping, 2016).

While policy formation has been somewhat indolent, reforms were included in police legislation giving a greater participatory role to local authorities and communities in crime prevention and community safety. The Garda Síochána Act 2005 set out two foundational pillars that form a potential structure for supporting the development of crime prevention and community safety. The first are Joint Policing Committees (JPCs) that are tasked to analyse crime and anti-social behaviour and advise local authorities and the police on strategies to address them. The second are Local Policing Fora (LPFs) which operate at local neighbourhood level and involve communities, local authorities and police working in partnership to engage in joint responses to crime and community safety problems (Bowden and Topping, 2016). Neither of these two emergent structures have been subject to systematic review or evaluation and so their impact remains unknown, although there is some evidence that relationships across sectors have been fraught (Harrington, 2011). 


\section{The Case: Childhood Development Initiative - Community Safety Initiative in}

\section{Tallaght West}

After briefly outlining the methodology used and describing the main stakeholders, the case material is presented around five organising pillars. The first concerns the context for the Initiative and how the promoters learned hard lessons from previous attempts to design and implement a model of community safety. The second will discuss the complexities of what is constructed as issues of 'safety' and 'security' which result from wider social stresses: lack of support services; racial and ethnic tensions associated with new in-fill housing developments added to established working class neighbourhoods. A third pillar of the case material briefly outlines the differences in approaches and mechanisms deployed in two distinct pilot sites. Zooming in on the implementation of the Initiative constitutes the fourth part of the organising framework. This pillar will centre on the impact of the Initiative as it engaged with the local authority structure together with the issues of creative tension between autonomy and standardised, manual-centred approaches. The case concludes by reflecting on the roles of both the local authority and the public police in respect of implementing the Initiative.

\section{Methodology}

The case is based upon a post hoc evaluation study commissioned by the Childhood Development Initiative. The article is based upon findings from interviews with stakeholders and focus groups with service providers and members of the local 
community. A household survey of the two sites where the Initiative was piloted is briefly referred to but not substantially utilised in this particular discussion. The Initiative was implemented between 2011 and 2012 and the evaluation commissioned a year later. Fieldwork was carried out during the Autumn of 2013 and a final report was later published by the commissioning body, the Childhood Development Initiative (Bowden, 2015). An earlier phase of the Initiative was implemented in the period 2009 to 2011 and subject to a separate evaluation. A timeline setting out these distinct stages is summarised in Table 1.

Table 1: Timeline for implementing the Tallaght West Community Safety Initiative, phases 1 and 2

\begin{tabular}{|c|c|c|c|c|}
\hline & Programme & $\begin{array}{l}\text { Implementation } \\
\text { agencies }\end{array}$ & $\begin{array}{l}\text { Key evaluation } \\
\text { finding }\end{array}$ & Evaluator \\
\hline $\begin{array}{l}\text { Phase } 1 \\
2009-11\end{array}$ & $\begin{array}{l}\text { Anti-social } \\
\text { behaviour } \\
\text { contracts in } \\
\text { two pilot sites }\end{array}$ & $\begin{array}{l}\text { CDI directly } \\
\text { delivers } \\
\text { Initiative }\end{array}$ & $\begin{array}{l}\text { No behaviour } \\
\text { contracts used - } \\
\text { problems with } \\
\text { community } \\
\text { engagement }\end{array}$ & $\begin{array}{l}\text { Child and Family } \\
\text { Research Centre, } \\
\text { National } \\
\text { University of } \\
\text { Ireland Galway - } \\
\text { Report } 2013\end{array}$ \\
\hline \multirow[t]{2}{*}{$\begin{array}{l}\text { Phase } 2 \\
2011-12\end{array}$} & $\begin{array}{l}\text { Customised } \\
\text { responses in } \\
\text { two new pilot } \\
\text { sites }\end{array}$ & $\begin{array}{l}\text { CDI, Local } \\
\text { authority } \\
\text { 'RAPID' staff }\end{array}$ & $\begin{array}{l}\text { Highlighted } \\
\text { proactive role of } \\
\text { local authority } \\
\text { and its staff as } \\
\text { agents of } \\
\text { community } \\
\text { safety }\end{array}$ & $\begin{array}{l}\text { Dublin Institute of } \\
\text { Technology } \\
\text { Evaluation } \\
\text { research } 2013 \text { to } \\
2014\end{array}$ \\
\hline & & & & $\begin{array}{l}\text { Report Published } \\
2015\end{array}$ \\
\hline
\end{tabular}


The researcher utilised a mixed methods tool kit within the realistic evaluation framework (Pawson and Tilley, 1997). Hence the research examined context (the conditions in the setting that require the introduction of measures / actions); mechanisms (the rationale and resources used to cause effects in the context) and outcomes (the practical effects generated by the mechanisms). This approach is similar to the linear assumptions of logic models which examine the flow between resources, activities, outputs and outcomes (Cooksy, et al 2001). However the short time frame for the Initiative did not auger well for producing definable outcomes. The evaluation aimed therefore, following Tilley (2009), to identify progress towards achieving outcomes.

With each interview or 'speech event' the researcher engaged in ongoing frame analysis using the method of strip resolution, which involves gaining understanding of the connections between the actors, actions and relationships by resolving questions with participants (Agar, 1996). Becker's (1979) guiding principles for qualitiative data analysis were used to identify intense themes: participants' accounts of the Initiative generated a conceptual map and an overview of the actions taken.

The mixed methods tool kit involved three main elements including a series of semistructured interviews with key stakeholders; a community survey of perceptions of residents in two pilot sites; and a series of three focus groups in the two sites as in Table 2. Interviews were primarily conducted with key stakeholder agencies and focus groups were organized for frontline staff and residents in the pilot sites. The latter were designed to triangulate findings from stakeholder interviews and the 
household survey. Participants were asked to comment on emerging findings in order to verify the substantive themes emerging.

Table 2: Summary of Research Methods Used

\begin{tabular}{lc}
\hline \multicolumn{1}{c}{ Method } & Number \\
\hline $\begin{array}{l}\text { Qualitative interviews with key } \\
\text { stakeholders }\end{array}$ & 15 participants \\
Household survey & 86 households \\
Focus groups x 3 & 12 participants \\
\hline
\end{tabular}

There are key limitations to the research arising from the fieldwork. Focus groups were limited by under attendance and a focus group organised for one of the pilot sites did not take place. This limited the researcher's capacity to fully assess in detail the relationships between residents and service providers in this site. In addition, the evaluation research is a retrospective study and commenced almost 15 months after the Initiative had been implemented. This shaped what respondents were able to report, given the passage of time between implementation and the fieldwork. The household survey, which is not substantially reported in this particular article, was also limited in this respect and therefore it was difficult to link specific mechanisms with perceived changes in quality of life.

\section{The Key Stakeholders}

The Childhood Development Initiative (CDI) began in 2003 to plan a strategy to improve child and family outcomes in Tallaght West and from 2007 to 2013 was one of three early intervention and prevention programmes supported by public and 
philanthropic funding. Prior to the foundation of the CDI, a research project into the needs and development challenges in the area, was carried out by the Dartington Social Research Unit (Axford et al, 2004). The CDI has since become part of the Irish Government's Area Based Childhood Initiative and it has since 2007 piloted and evaluated a number of interventions including community safety (see www.twcdi.ie). For the Community Safety Initiative, the CDI's Community Engagement Team (CET) brought together local stakeholders including housing associations, community groups, individual community leaders, estate management workers, the police service, and the Youth Service as summarised in Table 3.

Table 3: Roles of main stakeholders

\begin{tabular}{ll}
\hline \multicolumn{1}{c}{ Agency } & \multicolumn{1}{c}{ Role } \\
\hline $\begin{array}{l}\text { Local Authority RAPID } \\
\text { Staff }\end{array}$ & $\begin{array}{l}\text { Assessed needs in sites; implemented community safety } \\
\text { action plan; participated in Community Engagement } \\
\text { Team (CET) with CDI staff }\end{array}$ \\
$\begin{array}{l}\text { Childhood Development } \\
\text { Initiative (CDI) }\end{array}$ & $\begin{array}{l}\text { Funder; co-ordinated the task team (CET); } \\
\text { commissioned external evaluation }\end{array}$ \\
$\begin{array}{l}\text { Youth Service } \\
\text { Police Service - An Garda }\end{array}$ & $\begin{array}{l}\text { Participated in local steering groups in pilot sites; visited } \\
\text { not in Killinarden }\end{array}$ \\
$\begin{array}{l}\text { Síochána } \\
\text { Community Actors }\end{array}$ & $\begin{array}{l}\text { Integrated residents into community services; } \\
\text { participated in pilot site steering groups }\end{array}$ \\
$\begin{array}{l}\text { Housing Association } \\
\text { (landlord in Killinarden } \\
\text { site) }\end{array}$ & $\begin{array}{l}\text { Participated in activities and steering groups in } \\
\text { Killinarden site }\end{array}$ \\
\hline
\end{tabular}


The South Dublin County Council (SDCC) is one of the newest local authorities in Ireland following the division of Dublin County into three distinct areas under the Local Government Act 1994. The new local authority structures were formed to take account of changes in population following a period of sustained housing development on rezoned agricultural land and a process of population dispersal from the city centre to the periphery from the 1970s (MacLaren and Punch 2004; Punch 2002). The SDCC area has a population of $0.265 \mathrm{~m}$ (2011 census). Like all local authorities in the country, it is responsible for housing, planning, environmental health, parks, roads and traffic, and community services and development.

The Revitalising Areas by Planning, Investment and Development Programme (RAPID) was a local development programme to counter disadvantage in local communities and was co-ordinated by local authorities. The RAPID Programme wound down in 2010 and is no longer funded by the Government. A key focus for RAPID was working in partnership in local communities on issues including community safety and anti-social behaviour (Pobal, 2016). Local authority staff of the SDCC previously assigned to RAPID were temporarily redeployed on a part-time basis to the Community Safety Initiative in agreement with CDI.

Phase 1 of the Tallaght West Community Safety Initiative, 2009-2011

The assignment of the RAPID co-ordinators was conceived as Phase 2 of implementing the Community Safety Initiative from 2011 to 2012. Phase 1 was the subject of an evaluation by researchers at The Child and Family Research Centre, at 
National University of Ireland Galway (NUIG) (Kearns et al, 2013). Particular attention in the NUIG report focused upon the implementation of a Community Safety Contract, a technology transferred from the UK. However no contracts were implemented between 2008 and 2011: the authors suggested that this mechanism precluded stakeholder input into designing safety interventions to meet local problems in the target areas (Kearns et al 2013; Bowden 2015).

Having reassessed the learning from the first phase of the Initiative, the CDI took two critical steps towards mainstreaming it with existing structures and services:

1. Developed a Community Safety Manual to guide policy and practice;

2. Opened negotiations with the local authority with the view to deploying their staff to implement Phase 2 in two pilot neighbourhoods.

The Manual outlined the essential elements of a community safety strategy that could be adapted and replicated and offered a guide towards assisting neighbourhoods and stakeholders to adopt an evidence-based approach together with a framework for local participation. The Initiative's logic model or programme theory pointed out six aspects of the model specifying how key leaders would be identified; assessing community readiness; engaging the community; developing local steering groups; carrying out a safety audit and action plan (CDI, 2013).

The Complexities of "Safety": Manifestations and Impact in the Chosen Pilot Sites 
Using the Manual and local knowledge, two pilot sites were selected in 2011. Both sites were in-fill housing developments, constructed within or on the boundaries of, existing council housing. This meant that they had distinct demographic and spatial characteristics. In both sites, housing was allocated from the local authority housing waiting lists - residents of these new sites are drawn from a wide geographical area and had different mobility patterns to those of the host communities.

1. The Killinarden site consisted of 104 recently constructed houses facing a mature housing estate: most of the households had very young children, compared with the host neighbourhood which was built in the early 1980s and had substantially matured. To its rear was a relatively new estate of mixed tenure housing.

2. The Fettercairn site of approximately 100 dwellings was more ethnically and racially heterogeneous than its host neighbourhood. These distinctions were reported to be particularly marked in the Fettercairn site which had a higher concentration of households of African origin.

Both sites were consistently described in interviews as "interface areas": they might be regarded as interfaces between the old and the new versions of community in contemporary urban Ireland. The Initiative was working with new sources of tension and conflict as dimensions of safety:

We picked those two estates because they were relatively new both of them as pilot sites. And there were particular issues in Fettercairn in that there was a peculiar mixture of tenants. There was a feeling that there was racism going 
on there. There was in particular migrants from African countries and also from eastern European countries. So there was a feeling that the existing houses, beside the new estate were feeling put upon and maybe a little... I don't know there was a lot of comparing going on. So there was a little bit of racism bubbling up and that's why we picked there (SDCC staff 3).

In addition the 'interface' constituted the boundary lines between largely homogenous working class communities whose residents originated from the post 1970s population dispersal from the inner city (Bowden 2014; Punch 2002; Byrne, 1984) and a new diverse group in need of social housing including migrants from Europe and Africa. The issue of safety in these two sites was therefore highly challenging because they were complicated by issues of class, race and ethnicity. While both areas were chosen on the basis of different manifestations of 'anti-social behaviour' there was some realisation amongst the stakeholders that they were dealing with more complex issues. These differences shaped and also limited the impact of the responses that were mobilised (see Table 4 below for a summary of the different interventions in each site).

These factors seemed to speak to distinct issues of relative insecurity: the experiences of people living at the Killinarden site manifested in a sense of isolation and separation from surrounding estates. The residents were seen to live with this problem of being neither one nor the other, as if reflecting life on the interface. An established and respected community leader pointed out: 
[T]hey are still part of your community. It's not another estate. Half of them are considered [old council estate]. There's different entrances - the entrance to the pilot site is through [the old council estate] but if you are in a car you can't access the rest of [new mixed tenure estate] you'd have to come in from [another entrance]. The roads are subdivided. They are part of A but you have to go in through B. Do you understand? - subtle. And then does that cause 'well I live in A but you have to come in through B'. Do you know what I am saying - just subtle differences (Key Community Stakeholder, Killinarden Site).

In addition the new estates constituted distinct time-spaces when compared with the older estates: the capacity to participate is structured by labour market participation, as one service provider observed:

In new estates people are out at work and they are not back 'til 7 or 8 in the evening. It can be a hard thing. People [in the old estates] had the lack of facilities in the 70 s and 80 s to unite them. That's not there now. People are out at work and it can be hard to get them involved in the community (Key Stakeholder, Killinarden Site).

This complicates the basis of commonality between distinct groups of residents whose relationship to place is multiply distinguished by employment, mobility and migration. Thus community safety workers in this context were dealing with the implementation 
of housing policy and its social effects such as marginality, feelings of exclusion, resentment of the Other. Focus group data with stakeholders in the Fettercairn site revealed this issue clearly:

\section{Participant}

1: I remember probably going back a couple years ago there was some ASB started around the parade maybe by residents of the older houses. The young people (.) sparked by what you said, people got these new houses facing on to the old houses that were looking so attractive. That did create tension in the area. And ASB started to pick up.

3: $\quad$ As [name] said there the people looking over - the first thing they probably notice is that there is lots of non-nationals in there you know and sometimes the non-nationals have been a bit of an easy target, because they don't know their way around or they don't know whose the local young lads are.

MB: $\quad$ They don't have roots in the area?

3: They don't have roots in the area. Where ever they came from different parts of Ireland even. So definitely they were targeted.

2: $\quad$ Combined with that there is a sense of injustice maybe that you are looking across at the new facility. 
3: $\quad$ Yeah, yeah and the jealousy factor and they are looking over and saying in their head 'well these people are coming in from outside the country and they are getting a brand new house and I'm here in a leaky house'. There was definitely a bit of that going on.

The needs and issues in the Killinarden site had to do with helping neighbours to develop informal bonds with one another. The assumption here was that without these ties households would remain isolated: they would live in highly individualised patterns that were counter to constructing 'soft' surveillance, as might be expected in established communities. These complexities reveal the broad range of contributing factors to settling social housing developments, underlining the role of the local authority as a major provider and governor in this context.

\section{Differences in Mechanisms and Impact in Both Sites}

A household survey taken in the two neighbourhoods $(n=86)$ asking respondents if they perceived that there was a change in the estate in respect of crime, vandalism and various nuisance behaviours, revealed a more strongly felt sense of change between the areas. The research design and timeframe limited the extent to which an association could be made between the distinct results and the different mechanisms deployed in each site. In Killinarden where there was less direct micro level anticrime interventions and more community identity-building events, residents felt there was little or no change. 
In contrast almost two-thirds of respondents in the Fettercairn site perceived a fall in anti-social behaviour while there was no perceived change in racism. However it is understood from an analysis of mechanisms used by local authority staff in Fettercairn, that more focused and customised, community and individual household situational measures. In addition, working with the Youth Service, the Initiative funded additional inputs with a group of young people seen as being the source of the unwanted behaviours. The Fettercairn site therefore had a higher concentration and a broader spread of interventions compared with the Killinarden site summarised in Table 4.

Table 4: Key safety Issues, agencies mobilised and principal measures undertaken in the two pilot sites.

\begin{tabular}{|c|c|c|}
\hline & $\begin{array}{l}\text { Killinarden Site } \\
(100 \text { dwellings })\end{array}$ & $\begin{array}{l}\text { Fettercairn Site } \\
(100 \text { dwellings })\end{array}$ \\
\hline $\begin{array}{l}\text { Manifestation of Safety } \\
\text { Issues }\end{array}$ & $\begin{array}{l}\text { Isolation of residents } \\
\text { Lack of belonging } \\
\text { Nuisance behaviours }\end{array}$ & $\begin{array}{l}\text { Racially based anti-social } \\
\text { behaviour } \\
\text { Congregations of young } \\
\text { people outside new } \\
\text { dwellings } \\
\text { Nuisance experienced by } \\
\text { Particular residents }\end{array}$ \\
\hline $\begin{array}{l}\text { Key Agencies and } \\
\text { Partners Mobilised }\end{array}$ & $\begin{array}{l}\text { Local authority staff } \\
\text { Housing association } \\
\text { Residents } \\
\text { Community centre } \\
\text { CDI }\end{array}$ & $\begin{array}{l}\text { Youth service } \\
\text { Police } \\
\text { Local authority anti-social } \\
\text { unit staff } \\
\text { Community centre } \\
\text { CDI }\end{array}$ \\
\hline Situational Measures & $\begin{array}{l}\text { General environmental \& } \\
\text { aesthetic improvements to } \\
\text { front gardens, green areas, } \\
\text { walkways }\end{array}$ & $\begin{array}{l}\text { Fencing, alley gates, } \\
\text { chains for wheelie bins } \\
\text { Customised solutions for } \\
\text { individual households e.g. } \\
\text { CCTV, creating fenced } \\
\text { front gardens }\end{array}$ \\
\hline Social Measures & $\begin{array}{l}\text { Christmas and Halloween } \\
\text { parties, street barbeques and } \\
\text { community events to } \\
\text { encourage neighbourliness }\end{array}$ & $\begin{array}{l}\text { Funding for a youth } \\
\text { service intervention with } \\
\text { young people deemed 'anti } \\
\text { social'' }\end{array}$ \\
\hline
\end{tabular}




\section{Implementation of the Initiative}

Entering the Local Development Domain: Mobilising the Local Authority

The CDI used its funding to contract with the local authority to deploy staff, who had worked on RAPID, to the Community Safety Initiative. In this way the CDI levered time and autonomy. A CDI team member said:

A frontline worker wouldn't agree to do anything without checking back four times with somebody else. I felt sorry for anybody working at that level in the Council because it was just impossible. They had no autonomy. But also you can't freely co-operate with other people unless they have that kind of autonomy. (Member of CDI Team, 1).

The CDI recognised however that RAPID staff already had a wider network of contacts both internally in the local authority structures and in the community. In this sense the Community Safety Initiative was successful at forming a governing node: it enabled a horizontally and vertically integrated team to be put in place; and who had a clear mandate to 'zoom in' on safety issues. A senior council official described what the Initiative enabled was a more 'conversational' form of governing, as against an enforcement model. In addition, he pointed out that the Initiative was integrated into the work of the local council team: 
Rather than sitting around the table they were able to get out there and have that conversation. People need a voice and they need to be given a chance to do it separately - if they don't want it done publically. [The RAPID officers] can go out and have the conversation and feed it back into the Council team. CDI brings together the co-ordination of that. The RAPID has better contact outside the meetings; by having that conversation - its important how you deliver things - how you communicate (Senior SDCC Staff 1).

The Initiative was implemented by a cross-agency task-team which was comprised of the RAPID co-ordinators (local authority staff) and staff of the CDI. The respective staff managers in the local authority and the CDI provided line management. Neighbourhood steering groups in the two pilot sites also supported the Initiative. These were comprised of key local actors including estate management workers, community Garda, local people, and the Youth Service. In this way the Initiative was linked both vertically and horizontally in the context of the local authority and in the local community. Thus an embedded autonomy was achieved: a softening of strict and rigid bureaucratic governance enabling a developmental flexibility, similar to that achieved by state agencies as actors in economic development (Evans 1995; O'Riain, 2000)

Tension Between Autonomy and Manualised, Evidence-Based Approaches

Despite the many gains that the implementation of the Initiative made there remained a number of tense areas that need to be considered in advancing the community safety 
model. These issues related to working within in a results-oriented or outcomefocused approach; versus those less time bound and process-oriented. Moreover they appear to point to the creative tensions that exist between different institutional cultures and developmental models.

This was revealed in the view expressed by some local authority staff that the work they did, despite the funding, the manual and the cross agency task-team, was no different to the community based work they did as part of their normal routines. Recognising that the earlier phase of the Initiative, which did not prove successful in achieving its goals, and with specific reference to the community safety contract, as a local authority staff member pointed out:

Yeah. We had no interest flogging that dead horse. It just was a bad idea. ...So we went in knowing that we were just going to do things our own way. CDI want to make things look like it's new it's a new initiative you know. Brand new idea. Never done before...... It's just the same old community development that happens here all the time you know. There's nothing new about it. But what was new was maybe was the dedicated time and a concentrated (.) small space (SDCC staff 3).

This perception seems to suggest that there was a tension between the evidence based model in the Community Safety Manual, and the working knowledge of the local authority workers. Some research in this area of tension reveals the importance of 
working together on concrete tasks and partners getting to know one another (Mayan et al, 2016). Manualised, evidence-based models might have to remain suitably flexible to activate the embedded autonomy of the community safety worker as a practical problem-solver.

The Community Safety Worker within the Local Authority Structure

The Initiative was jointly governed by a memorandum of understanding between the CDI and the local authority (SDCC). The senior local authority manager responsible deployed RAPID staff to the Initiative for an agreed term of one year. In the evaluation study the local authority participants pointed to enhanced learning on collaborative approaches, as a senior official pointed out:

You can take it this is how we are going to work. We have done it since in [housing estate], we had problems up there. There was a couple of families with problems and there was nothing being done. We moved some people [staff] up to talk to them and we set up an environmental group a community safety group and the events group and it solved the problem (Senior SDCC staff 1$)$.

The Initiative also helped SDCC senior staff to think about the person specification for a community safety professional who resolves problems by joining up the contributions of dispersed actors through intra and inter agency linkages, while developing a profile of trust locally. This is a role for a professional with 
communicative capacity to integrate an official role, an action-oriented approach and community networking skills:

Yes you need a person who works - the right type of person who can use supports of other departments to get things done and not a punitive person giving out fines - someone who people will be glad to see coming along. Someone has to gather up all the problems in an area - list them and throw it in and then you have a piece of paper that's going to hop from one desk to another - there's got to be a connect (Senior Local Authority Manager).

\section{Police Engagement and Involvement with the Initiative}

Through the Joint Policing Committee, local authority and An Garda Síochána implemented a series of crime prevention and community safety actions throughout Tallaght and South Dublin County. While the Community Safety Initiative had local police input, it operated with minimal involvement from police management. At the implementation level however community Garda, an officer dedicated to locally based problem solving in the Fettercairn site, was a member of the steering committee in one of the pilot sites and had day-to-day contact with the implementation of the Initiative. A Garda sergeant and a Council official were also involved in visiting homes of young people to underline to parents the statutory powers available to the Council should incivilities persist. The goal of this intervention was to encourage young people to engage with the Youth Service through its Garda Youth Diversion Project. Apart from these two discrete inputs, the Initiative operated without input from police management. 


\section{Discussion}

Commenting on safety and security in former Yugoslav republics Meško et al (2013) have pointed to the deeper roots of safety as critical dimensions shaping urban security and insecurity. Sources of insecurity and threat include economic decline, precarity in employment, alongside issues of crime and incivility. These issues experienced in the neighbourhoods may manifest in practical issues of safety but are related to marginality, change and absence of social cohesion. This poses the challenge of choosing the right mechanisms within logic models for dealing with underlying complexities as well as their manifestations. A universal challenge therefore is whether community safety is the right fix to urban marginality? However, using a mix of situational and social measures as in the case of the Fettercairn site in particular shows some progress towards a model that is inclusive and participative. In this neighbourhood, individuals and sites were selected for customised environmental crime prevention measures alongside integrating young people more closely with the preventive activities of the Youth Service.

The research highlights the proactive role that the local authority played in this case, and that of the originator and devisor of the Initiative, the CDI. The Initiative mobilised customised security and preventive responses that appeared to be critical in the impact of the Initiative in the Fettercairn site especially. This proactive role of the local authority enabled local security with accountability through problem solving and civic engagement. The approach runs counter to the politics of 'making people behave' which characterised the ASBO driven policy on low-level crime control in 
the UK during the 1990s and early 2000s (Burney, 2009). Such approaches 'defined deviancy up' and set in place a self-regulatory politics; it failed to understand how regulation works in interaction with the wider sets of institutions and informal controls that regulate behaviour (Lewis, et al 2016). The proactive approach shown in the case, is qualitatively different from the use of legislative orders to remove or chastise problem tenants. Despite having access to such instruments available under the Housing Miscellaneous Provisions (Amendment) Act 1997, the SDCC has been a willing partner in a practice of engagement as stimulated by the designers and promoters of the Tallaght West Community Safety Initiative. The use of both situational and social measures targeted at young people underline the need for integrated preventive ecosystems such as that piloted by the CDI.

Glancey et al (2012) have pointed to the multiplicity of roles played in the context of Community Safety Officers (CSOs) in the local authorities in New South Wales highlighting that played in the formulation of crime prevention plans. A proactive role designing out crime and developing responses to areas such as domestic violence and social prevention with young people are also dimensions of the CSO role in New South Wales. Despite the emergence of a number of initiatives in the Irish context, there remains little clarity of focus and little by way of developing support structures for community safety and urban security as mainstream functions of government.

By virtue of its remit in respect of social housing in the Irish context, local authorities are poised to deliver a more responsive model of government in areas most distant from power centres. Housing agencies might be seen as more responsive in following 
up on issues of nuisance and unwanted behaviours (Brown and Evans, 2014) and poised also to co-ordinate inclusive and collaborative strategies for 'co-designing' out crime (Camacho Durate, 2013).

\section{Conclusion}

Local authorities have increasingly become players in governing urban security, partly in response to the United Nations initiatives such as the Safer Cities Programme (United Nations Habitat, 2012). Despite this framework, little discussion has taken place in the Irish context as to how this manifests itself in the everyday life of constructing safety in neighbourhoods. This article highlighted the role that local authorities play in mobilising community safety work, together with an account of the community safety worker as a problem solving agent of local governance; responding to aspects of the local context that contribute to crime, insecurity and incivilities. This approach reflects a distinct type of knowledge that is in tension with the "what works', evidence based discourse. Cherney and Sutton (2004) described this as 'know-how knowledge' (as knowing how governing works and understanding how to transform it); and 'know-who knowledge' as network mobilization to help solve problems. However rather than being the radical agent of transformative change (Hughes et al, 2002) the community safety workers in this case speak more to the power of embedded autonomy to make bureaucratic structures more flexible and governance more responsive. 
The case presented also highlights the nature of incivilities as resulting from misperceived advantages to ethnic and racial minority tenants. Part of the work of community safety in the Fettercairn site in particular was sensitive to the tensions of integrating tenants from minorities into neighbourhoods, which had for generations, housed the white working class. This potentially brings community safety policies and practice out of the domain of behaviour regulation and into that of social cohesion. Indeed managing the tensions at the neighbourhood level as observed in this case frames community safety and urban security with its related toolkits as part of the frontline work of social integration.

\section{Acknowledgement}

I wish to thank the Childhood Development Initiative for permission to use data extracts and other relevant text from the original evaluation report, available from www.twcdi.ie

\section{References}

Agar, M. H. (1996) The Professional Stranger: An Informal Introduction to Ethnography. San Diego:Academic Press.

Axford, A., Little, M., Duffy, L., Haran, N., and Zappone, K. (2004) How Are Our Kids? Children and Families in West Tallaght. Dublin: Childhood Development Initiative. Becker, H. S. (1979) Problems of Inference and Proof in Participant Observation. In J. Brynner and K. Stribley (eds) Social Research: Principles and Procedures. London: Longman. 
Bowden, M. (2006) Youth, Governance and the City: Towards a Critical Sociology of Youth Crime and Disorder Prevention, Youth Studies Ireland. Vol.1, No. 2, pp 19-39.

Bowden, M. (2014) Crime, Disorder and Symbolic Violence: Governing the Urban Periphery. Basingstoke: Palgrave Macmillan.

Bowden, M. (2015) Evaluation Report: Community Safety Initiative - Assignment of the RAPID Co-ordinators. Dublin: Tallaght West Childhood Development Initiative. Bowden, M., and Higgins, L. (2000) The Impact and Effectiveness of the Garda Special Projects : Final Report to the Department of Justice, Equality and Law Reform. Dublin: Stationery Office.

Bowden, M., and Topping, J. (2016) Crime Prevention and Community Safety. In Healy, D., Hamilton, C., Butler, M. and Daly, Y. (eds) The Routledge Handbook of Irish Criminology. London: Routledge.

Brown, R., and Evans, E. (2014) Determinants of complainant satisfaction with agency responses to anti-social behavior. Crime Prevention and Community Safety. Vol. 16, No. 2, pp 105-127.

Burney, E. (2009) Making People Behave: Anti-Social Behaviour, Politics and Policy. Cullompton: Willan.

Butler, S. (2002) Alcohol, Drugs and Health Promotion in Modern Ireland. Dublin: Institute of Public Administration.

Byrne, D. (1984) Dublin - a Case Study of Housing and the Residual Working Class, International Journal of Urban and Regional Research. Vol. 8, No.3, pp 402-420.

Camacho Duarte, O. (2013) Can design support community safety and crime prevention programmes in areas of socio-economic disadvantage? Crime Prevention and Community Safety. Vol. 15, No. 3, pp 223-239.

Cherney, A., and Sutton, A. (2004) Aussie experience: local government community safety 
officers and capacity building. Community Safety Journal. Vol. 3, No. 3, pp 31-36.

Cooksy, L. J., Gill, P., and Kelly, P. A. (2001) The program logic model as an integrative framework for a multimethod evaluation. Evaluation and Program Planning. Vol. 24, No. 2, pp 119-128.

Edwards, A., Hughes, G., and Lord, N. (2013) Urban security in Europe: Translating a concept in public criminology. European Journal of Criminology, Vol. 10, No.3, pp $260-283$.

Evans, P. B. (2012) Embedded Autonomy: States and Industrial Transformation. Princeton: Princeton University Press.

Fahey, T. (ed) (1999) Social Housing in Ireland: A Study of Success, Failure and Lessons Learned. Dublin: Oak Tree Press.

Garland, D. (2001) The Culture of Control: Crime and Social Order in Contemporary Society. Oxford: Oxford University Press.

Gilling, D., Hughes, G., Bowden, M., Edwards, A., Henry, A., and Topping, J. (2013) Powers, Liabilities and Expertise in Community Safety: Comparative Lessons for 'Urban Security' from the United Kingdom and the Republic of Ireland. European Journal of Criminology. Vol. 10, No. 3, pp 326-340.

Glancey, G., Lee, M., and Crofts, T. (2012) 'We're not Batman' - Roles and expectations of local government community safety officers in New South Wales. Crime Prevention and Community Safety. Vol. 14, No. 4, pp 235-257.

Harrington, D. (2011) Partners Against Crime: A Review of Partnerships in Joint Policing Committees. Dublin: Dublin Institute of Technology.

Hourigan, N. (ed.) (2011) Understanding Limerick: Social Exclusion and Change. Cork: Cork University Press.

Hughes, G. (2007) The Politics of Crime and Community. Basingstoke: Palgrave Macmillan. 
Hughes, G., \& Gilling, D. (2004). 'Mission Impossible'? The Habitus of the community safety manager and the new expertise in the local partnership governance of crime and Safety. Criminal Justice, Vol. 4, No. 2, pp 129-149.

Hughes, G., McLaughlin, E., and Muncie, J. (2002) Teetering on the Edge: The Futures of Crime Conrol and Community Safety. In Hughes, G., McLaughlin, E. and Muncie, J. (eds) Crime Prevention and Community Safety: New Directions. Milton Keynes: Open University Press.

Kearns, N., Reddy, J., and Canavan, J. (2013) Evaluation of the Community Safety Initiative of the Childhood Development Initiative. Dublin: Childhood Development Initiative.

Lewis, S., Crawford, A., and Traynor, P. (2016) Nipping Crime in the Bud? The Use of Antisocial Behaviour Interventions with Young People in England and Wales. British Journal of Criminology, online first $19^{\text {th }}$ September 2016

MacLaran, A., and Punch, M. (2004) Tallaght: The Planning and Development of an Irish New Town, Journal of Irish Urban Studies, Vol. 2, No. 1, pp 17-39.

Mayan, M., Lo, S., Richter, S., Dastjerdi, M., and Drummond, J. (2016) Community-Based Participatory Research: Ameliorating Conflict When Community and Research Practices Meet. Progress in Community Health Partnerships: Research, Education, and Action. Vol. 10, No. 2, pp 259-264.

Meško, G., Tominc, B., and Sotlar, A. (2013) Urban Security Management in the Capitals of the Former Yugoslav Republics, European Journal of Criminology, Vol. 10, No.3, pp 284-296.

O'Riain, S. (2000) The Flexible Developmental State: Globalization, Information Technology and the "Celtic Tiger", Politics and Society, Vol 28, No. 2, pp157-193.

O’Connell, C., and Fahey, T. (1999) Local Authority Housing in Ireland, In Fahey T. (ed) Social Housing in Ireland:A Study of Success, Failure and Lessons Learned. Dublin: 
Oak Tree Press.

O'Gorman, A. (2014) Social (Dis)Order and Community Safety, In Norris M. (ed.) Social Housing and Liveability: Ten Years of Change in Social Housing Neighbourhoods. New York: Routledge.

Pawson, R., and Tilley, N. (1997) Realistic Evaluation. London: Sage.

Pobal. (2016) RAPID Dublin: Pobal. https://www.pobal.ie/FAQ/Pages/RAPID.aspx

Punch, M. (2002) Local Development Issues on the Periphery: Tallaght from the Bottom Up. Journal of Irish Urban Studies. Vol. 1, No. 1, pp 61-77.

Sargent, P. (2014) Wild Arabs and Savages: A History of Juvenile Justice in Ireland. Manchester: Manchester University Press.

Shearing, C., and Wood, J. (2003) Nodal Governance, Democracy, and the New 'Denizens', Journal of Law and Society, Vol. 30, No. 3, pp 400-419.

Tallaght West Childhood Development Initiative (2013) Community Safety Initiative:

Programme Manual. Dublin: Tallaght West Childhood Development Initiative.

Tilley, R. (2009) Crime Prevention. Cullompton: Willan.

United Nations, (2012) United Nations Habitat: Safer Cities Programme, http://unhabitat.org

Wood, J., and Shearing, C. D. (2007) Imagining Security. Cullompton: Willan. 